\title{
UNELE PROBLEME REFERITOARE LA DATAREA TEZAURULUI DE LA SUCEAVA
}

CRISTINA ANTON MANEA

là 1653, pentru! a doua oarà, oastea căyàceascà condusă de Timuts Humelnitki a trecut hotarul Moldovei in ajutorul lui Vasile Iupu si s-a inclreplat spre celalea Sucevei. unde rảmảsese inchisả "casa lui Vasile vodả și jnima loata. “aci acolo iṣt làsase pre doamma lui și averea și pre fecioru-sãu".

Ajunși la Suceavia, sul, amenințarea apropierii oṣtilor polone duṣmane. rakacii "au apucal să se ingroape. să arunce șanturi imprejur, nu la ce loc sulpl

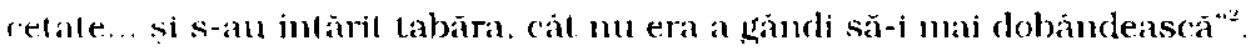

Dar. monjumati. asediati si hätulti. cu pierderi grele in oameni. "anu

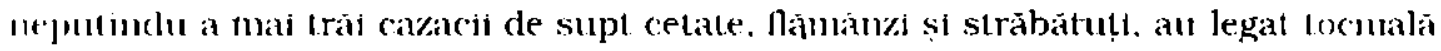

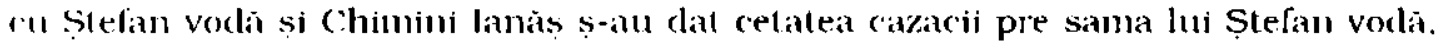

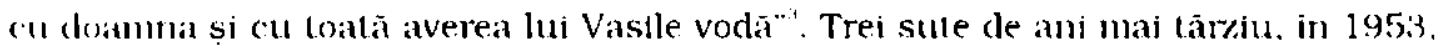
acest episod din istoria Motclovei a rost clescifrat prin săpături ajlueologice untreprinse pe platoul din fata cetătii. la locul numit "Campul Santurilor".

Cu arest prilej. in peretii uneia dintre cele 10 gropi ale sistemului defensiv razacesc despre care ne vorbeșle cronica s-au gäsit două lezaure: mul compus din

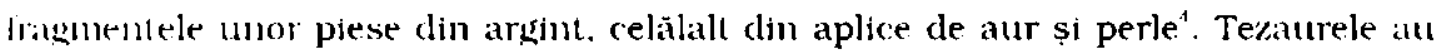
apjoṭmul unuia dintre cazacii care "cum au sosil la celate, de a doa zi s-aul

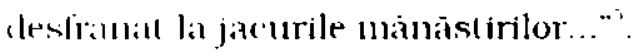

Anubele lezaure reprezinlá procentul din intreaga pradá ce i-a revenil

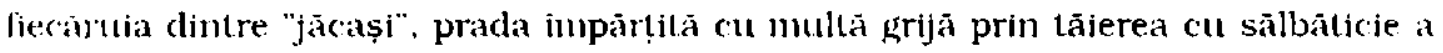
ımon piese a căror manoperā se ridica mult peste valoarea melaluhui din care eraı lucrale.

In randurile ce unneazà ne vour ocupa de cel de-al doilea tezaur, compus din piesse de aur. Acesta este alcātuil din:

- 147 de aplice de aur in greulate totala de 134.14 gr.

- 4 fraginente de podoabà din aur și perle de 16 gr.

- 8 faite dreptunghiulare de aur de $11,25 \mathrm{gr}$.

- G placi dreptunghiulare de lumgimi diferite de $79.63 \mathrm{kr}$. 
- I fragment dintr-o placià dreptunghiularã de 4,78 gr,

- 5 verigi duble de aur in greutate de $1.70 \mathrm{gr}$.

- 745 perle naturale, baroc, moarte.

Cele 147 de aplice se impart in 12 grupuri, după cum unnează:

1. Zece conuri din foaie de alır cu suprafata acoperità de cercuri diir lir

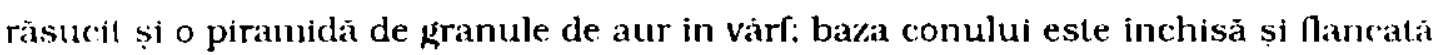
de douá tuburi micj canelate.

I=8 unm, La=12 mm, G tolalä=5,8 gr, AU 375\%o, nr. jnv. $9692-9701$. (figg. 3)

2a/. Oplsprezece aplice in fomnà de Moare din foaie de aur. cu conturul neregulat. din care pornește un peduncul lat. întors spre dreapla: conturul aplicet este din două fire netede, iar suprafạ̣a interioară acoperitã cu bucle din fir rāsucit. In centrul norii, pe trei petale și pe peduncul sunt perforații de prindere. inconjurate de 1 in inel din fir lorsionat.

I. intre $=20$ și $22 \mathrm{~mm}$. D intre= 14 și 16 mm. G intre=0.47 și 1.07 Gr. Al) $500 \%$, nr. inv. $9702-9716,9718-9720$ (fik. 15).

b/. Aplicai in fonmă de floare similară cu piesele de la poziția 2a. clar are conturul marcał de un fir răsucit.

l,=20 mm, La=14 $\mathrm{mm} . \mathrm{G}=0,74 \mathrm{gr}, \mathrm{AlJ} 500 \%$ o, nr.inv. 9717 (fig. 18)

c/. Doua aplice in Conuá de Moare similare cu piesele de la pozitia 2a. diar au pedunculul intors spre stànga, iar conturul marcat de un fir răsucit.

L. intre $=20.8$ și $22.5 \mathrm{~mm}$. L a intre=14.3 și $17.3 \mathrm{~mm}$, G intre=0.57 și $0.90 \mathrm{gr}$, All 500\%, nr. inv. 9721 - 9722 (fik. 17)

d/. Aplică in [onıă de noare similară cu cele de la pozițja $2 c$, dar conturul este maarcat de douá fire răsucite.

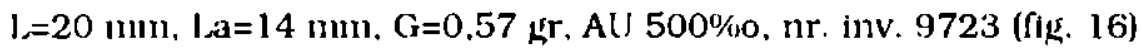

e/. Patru aplice in formã de floare similare cu cele de la poziția 2a, dar cu conturul marcal de granule sferice, dublate din loc in loc.

L intre=21 și $23 \mathrm{~mm}$. La intre= 15 și $17 \mathrm{~mm}$, G intre=1.26 și $1.45 \mathrm{gr}$. At: 500\%o, nr. inv. 9724 - 9727 (fig. 19)

f/. Trei aplice in formă de floare similare cu plesele de la pozlția $2 \mathrm{c}$, dar cu conturul marcat de granule sferice, dublate din loc in loc.

L intre=2l și $23.6 \mathrm{~mm}$. La între=15 și $17 \mathrm{~mm}$, G între=l,25 și $1.59 \mathrm{gr}, \mathrm{AU}$ $500 \%$, nr. inv. $9728-9730$ (fig. 20) 
3. Oplsprezece aplice in Conıă de rozelă cu șase petale circulare din lir lorsionat. dispuse in jund unei granule sferice de aur așezate pe un inel din fir. clispuse pe o foaie de aur; in fiecare petală se inscrie cîte un cerc din lir torsionat. ial pe marşine sunt așezate șase inelușe de prindere.

$\mathrm{D}=13.8 \mathrm{~mm}$, G intre=0.45 și 0.57 gr, AlJ 500\%o, nr. inv. 9731 - 9748 (fig. 13)

4. Aplicã in fonnà de rozelā cu șase pelale alungite din fir torsionat. care fomuraza in vàtul fiecărei petale douá cercuri minuscule. iar intre petale càte un rerc. iar in mijloc. o granulà sfericà. Filigranul este dispus pe o foaie de aur.

$\mathrm{D}=15.6 \mathrm{~mm}, \mathrm{G}=0.74$ kr. AU 375\%o, nr. inv. 9749 (fig. 8)

5. Aplică in fonmà de rozetã cu șase petale rombice din fir torsional dispus pe o foaje de aur. cu cate un cerc pe fiecare pelalà și intre petale: trei din cercurile exterioare suml perforale pentru prindere.

$\mathrm{D}=13.6 \mathrm{wm} . \mathrm{G}=0.56 \mathrm{kr}, \mathrm{AU} 375 \%$ o. nr. inv. 9750 (fig. 7)

6. Pattu aplice in fornă de rozelá cu șase pelale circulare din fir torsional (lispuse in jurul unui cerc central și așezate pe o foaie de aur; in fiecare petală și ıl rentru mai este inscris un cerc. iar pe margine sunt ineluse de prindere.

$D=14$ um. G intre=0.39 gr și 0.49 kr. AU 375\%, nr. inv. 9751 - 9753. 9860 (fiagnment) (fig. 5)

7a/ Doudzeci si donà de aplice in fonmà de mänuse cu trei lobi. pe foaie de atur. laturile arcuile spre interior saut ondulate: conturul figurii este realizal din doná fire nelede. iar suprafața inlerioară acoperilă cu șiruri de bucle din fir Iursionitt. İ mijloc și la extremitặ̣le figurii este câte o perforație inconjuratả de un incl din fir torsionat.

I intre= 16 și $20 \mathrm{~mm}$. La intre=10 și $15 \mathrm{~mm}$, G intre=0.59 și 0.90 gr. AU $583 \%$, nr.inv. $9754-9775 .($ fik. 21)

b/ Douã aplice in Connà de mánuse similare cu cele de la poziția $7 a$, dar conturul marcat de un fir torsionat.

$\mathrm{l}=18 \mathrm{~mm}, \mathrm{La}=12 \mathrm{~mm}, \mathrm{G}=0,59$ și $0.64 \mathrm{gr} . \mathrm{AU} 583 \% \mathrm{o}, \mathrm{nr}$. inv. $9776-9777$ (fik. 23)

c/ Cinct aplice în fonmă de mânuse, similare cu pisele de la pozițla 7a, dar cul conturul marcal de un fir neled și unul torsionat.

I intre=17 și $19 \mathrm{~mm}$, La intre=10 și $11 \mathrm{~mm}$, G intre=0.63 și $0,70 \mathrm{gr}$. Al1583\%o, nr. inv. $9778-9782$ (fig. 22) 
d/ Sase aplice in formá de mâniuse similare cu piesele de la poziția 7a dar cu conturul marcat de un șir de granule sferice, dublate din loc in loc.

I intre= 19 ș1 $21 \mathrm{~mm}, \mathrm{La}=12 \mathrm{~mm}$. G intre=1.04 și 1.64 gr. AU 583\%, nr. Inv. 9783 - 9787, 9858 (fraginent) (fig. 24)

8. Patruzecl stuna de aplice pentagonele din foale de aur pe care două fire netede înscriu o figurá fonnatả dintr-un dreptunghı șl o jumătate de rozetả lobatā. unite în partea centrală: suprafața figuril este acoperitã cu bucle dín fir torsionaı: in mfjloc și la extremıtățle aplicei sunt perforațil de prindere inconjurale de càte un Inel torsionat. $\mathrm{Cu}$ excepța unui sthgur exemplar, toate aplicele au foaia de aır decupatã pe conturul dubleí figuri.

I intre=16 și $25 \mathrm{mni}$, I a intre=15 și $19 \mathrm{~mm}$. G intre=0.75 ș1 $1.37 \mathrm{gr}$. Al I 500\%o, nr. Inv. 9788 - 9826.9855 - 9857 (fragmente) (fig. 9)

9a/ Douảzecı sıpatru de aplice pentáuónale din foale de aur pe care un fir torstonal inscrie o figurà compusá dintr-un dreptunght și un semicerc. unile inlre ele printr-un gát. Suprafața aplicel este acoperitả de un șir de bucle din fir torsionat. In centru și la extremitățle aplicel sunt perforatil de prindere inconjurate de câte un fir torsionat.

Cu excepția unui singur exemplar, toate aplicele au foale decupalà de-a lungul conturului dubles figuri.

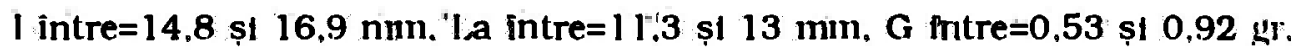
ÁU 500\%o (fig. 11 )

b/ Aplică din foale de aur decoratả cu filigran, similară cu piesele cle la pozițla 9a. dar cu o preforațle mare. ovalả in mbjloc.

I=13 mm, La=12 mm, G=0,93 gr, AU 500\%o, nr. Inv. 9850 (flg. 30)

10. Aplică in fonna de floare de crin din foaie de aur, cu conturul pelalelor dın fir torsionat; în vârf și lateral sunt ineluṣe de prindere.

I=14 mm, La=15 mm, G=0.65 gr. AU $583 \%$ o. nr. Inv. 9853 (fig. 12)

11. Douảaplice in fonnả de rozetá cu trel petale rombice ṣl irei rolunde. din fir de aur torsionat, sudat pe foaie de aur: între petale. inelușe de prindert.

$\mathrm{D}=15 \mathrm{~mm}, \mathrm{G}=0.64$ și 0.65. All 500\%o. nr. Inv. 9851 - 9852 (fils. 6)

12. Aplicả pătratá din foàle dè aúr bordatá cu un fir toŕsionat. curbal in Interiorul pătratuluı unde forınează o treflă in mijloc și douã jumătăți pe margine. Suprafata Interioará este acoperitá de' bucle din fir 'lorsionat. İ́n centru și la extremitățlle aplicel sunt perforațil de prindere, inconjurale de cấle un inel din fir 
torsionat. Foala suport a fost decupatā de-a lungul firului de contur in zona ondulată.

L=12 mm, La=1 1.4 min. G= $0.63 \mathrm{gr}, \mathrm{AU}$ 900\%o. nr. Inv. 9854 (fig. 14)

A/ Două fraumente de podoabă din aur sl_perle formate din dot ctlindrit alāturați și douả tuburi subțirı. mal inalte, intre el. totul sudat pe o foate de aur, suport. Suprafața cilindrilor este realizatã din douã registre de pamblicá finá ondulatã. despărțite de o tresă din două fire. și o alta deasupra cu trei fire. in partea superioarả. Cilindrele sunt inchise deasupra cu disc din cercuri de fir lorsionat și un șir de granule pe marğine. Baza este inconjurată de un șir de śranule. Tuburile sunt din foaie netedă cu o granulă în vàrf:

la baza piesei. de o parte și de alta. sunt sudate două și respectiv. trei verigi perechi. tangente la o a trela cu suprafața canelata. Printre ele se treceau nituri cu perle la capete.

$I_{a}=20.9 \mathrm{~mm} . \mathrm{Gr}=10,9 \mathrm{~mm}, \mathrm{G}=3.67$ și $3,97 \mathrm{gr}$. AU 750\%o, nr. Inv. 9866 98677 (lik. 1$)$

B/ Douả fraumente de_podoabă din_aur si_perle_fonnate din dol cllindrif alăluraț cu un tub subțire intre el, tolul sudat pe o foaje de aur suport. Suprafața cillindrllor este realizată dintr-o bandă subțire. ondulată. sudată la partea superioarà de un Inel dintr-o tresă bordatâ cu piramide de granule. Pe capacul cilindrelor. cizelat ca și la plesa de la poziția a. este fixatà càte o perlá naturalà, print r-un nit din metal comun.

Tubul este lucrat dintr-ın fir in spirală și are deasupra o granulă. La baza piesei sunt sudate aceleași verigi dín bandả de aur ca la piesele de la poziția a. și douá inele duble cu granulà de aur ca la poziția f:

$L_{\mathrm{A}}=20.8 \mathrm{~mm} . \mathrm{Gr}=10,9 \mathrm{~mm} . \mathrm{G}=4.95$ și $3.41 \mathrm{gr}$ (fragment). AU $750 \%$. nr.inv. $9868-9869$ (fik. 2)

C/ Opt folte dreptunghiularedin aur cizelate cu motive vegetale stilizate. fructe și frunze intr-o rețea de volute și steluțe inscrise intr-un cadru perlat au repousse.e.

$\mathrm{I}=70 \mathrm{~mm} . \mathrm{I}=30 \mathrm{~mm}$. G total= $11.34 \mathrm{gr}, \mathrm{AU}$ 500\%o. nr. Inv. $9677 \cdot 9684$ (liis. 10)

D/ CinclplăcL dreptunghiulare de lungimi diferite din aur cu baghete late. subṭiri și șiruri de perle au repoussee, dispuse alternativ. Trei dintre ele prezintã câte o porțiune netedă la un capăt, jar una dintre ele la ambele capele. 
L intre $=19$ și $93 \mathrm{~mm}, \mathrm{La}=29 \mathrm{~mm} . \mathrm{G}$ totală= $79,63 \mathrm{gr}, \mathrm{AU} 375 \%$ o, nr. Inv. 9687 - 9691.

E/ Fragment dintr-o placá decorativā de aur aproximativ dréptunghíulară, cizélată cu volute netede pe un fond stanțat cu cercur minuscule. de-a lungul marginil drepte a plăcil este o pamblică ingustă. ondulată.

$\mathrm{L}=43 \mathrm{~mm}, \mathrm{G}=4.87 \mathrm{gr}, \mathrm{AU} 900 \%$, nr. Inv. 9870 (fig. 25)

F/ Cincilverigl duble din bandả de aur, cu capetele intoarse'spre interior formảnd cảte o buclā, între ele esté sưdată o granulă sfericã din aur.

$\mathrm{L}=8 \mathrm{~mm}, \mathrm{G}$ tólal= $1.70 \mathrm{gr}$, ÁU 583\%o, nr. Inv. 9861 - 9865 (fig. 4)

Cele 12 tipuri de aplice și cele patru fragmente de podoabă par să fi aparținut unuia și aceluiași obiect, în timp ce plăcile decorative precumı și cele cincl verigi de prindere, unor plese diferite.

Totuṣı. la aplice și podoabe rezultatele análizel compoziției metalului prețios, respectiv caratajuu stabıllit de BNR. variazã sensıbil de la un grup la altul. de la 375 la $900 \%$.

Dar și dimensiunile sunt uṣor direrite in cadrul acelulașı tıp, după cum se poate constata dín descriere. cu excepța celor de tip 1 - conurile tipul 3, 4'și 6 rozetele și parțial tipul 8 și $9 a$ pentru care s-au folosit aceleași șabloane la decuparea foli de aur pentru cite un lot de exemplare.

În schimb. la florlle cu pedunculul intors șl la cele în fonnā de mănușe. conturul a fost trasat liber pe foala de aur, numal cu unele repere.

In céa ce privește firele torsionate și cele netede ce bordează și acoperă suprafața aplicelor, se poate observa cu ochiul liber că grosimea lor este varlabilă la una și aceiași plesá, precum și de là una la alta. Chiar și tensionarea firelor la filigranul rāsucit esté evident 'mai stránsả sau maí largă pe diversele lor porțiuni.

Cu ajutorul microscopului metalografic s-a putut constata că firele sunt de fapt niște bentițe a căror grosime óscileazá aproximativ între 0.15 și $0,25 \mathrm{~mm}$.

Foaia de aur a fost decupatā cu ajutorul dăltițelor, lar perforatilile s-au făcut in inod neglijent, dupä sudarea fligranului,! adicá a cercurllor care le marcheaza, de jos in sus. 
La fiecare aplicả inelul din mîjloc: are diametrul mai mare decât cele de pe illargine.

Bordura perlată de la unele aplice și cea de la fragımentele de podoabã este lucrată din granule absolut sferice sudate intre ele pe marginea foil de aur (fig. 28).

Foaia de aur suport este foarte subțire. prezintă plesnituri și perforații fíne: fraguilitatea ei ca și cea a decorului pledeazã pentru un suport cu elasticitate redusã. puṭin supus tensionăril.

Suportul rămānea in mare parte descoperit, pentru cã aplicele nu se imbinau intr-un motiv decorativ compact. lar suprafața liberă era probabil acoperită cu perle sau pasinanterie.

Cele 745 perle au intrat cu siguranțā in compoziția motivului decorativ. atàt pentru sublinierea acestuia, spre exeinplu, a conturului aplicelor, cât și fixate. in ilijlocul acestora, pe inelul de fir cu diainetrul mai mare, ca intr-un cuib.

O perlā strābătutả de un nit din metal comun, la descoperirea tezaurului ne-a sugerat această posibilitate.

Dificultatea recompunerii inotivului decorativ. mai ales datoritā nuinārului neannonios de exemplare și modele de aplice ce ni s-au păstrat, nu aın putut sã o depășesc: nici cu ajutorul celor 52 de piese asemănătoare ca fonnă și dimensiune păstrate la muzeul mănăstiriı Putna'.

Este vorba de aplice din filigran pe foaie de aur dintre care 29 sunt similare celei de tipul 9b. 12 celor de tipul 6. iar celelalte 11 au fonnā de rozetā. Toate au in inijloc cáte o caselá circulară, cu perete drept și câte o piatră roṣie. albastră, verde sau albă.

Ele au fọst gãsite de către eguinenul Venedict intr-unul din monnintele bisericíi mânăstirii Pulna. la 1758, pe când biserica, intr-o stare jalnicã, "era fără acoperiṣ și ploua inăuntru“. Egumenul a vrut sả foloseascả odoarele la reparaṭia bisericil, dar mitropolitul lacov Putneanu 1-a cerut acestuia intr-o scrisoare. "ca pietricelele acele ce s-au aflat și sārjile și boldurile și altele ce s-au aflat pe mort sã impndobeascã o icoană a Maicii Domnului"“7.

Pe dosul izvoduluí prinit de la initropolit. egumenul precizează că este vorba de inornmântul din naos ${ }^{n}$.

Pe acesta, Dimitrie Dan 1-a atribuit lui Ștefan cel Mare. la publicareiı monnintelor de la Putna, dupả deschiderea lor, din 1856, prin înprejurarea cā in acest monnânt s-au aflat sãரji care nuinai doınnitorul Ștefan au putut sả le aibả". 
Acest considerent, precum și similitudinea dintre piesele de la Pul ha și cele de la Suceava i-au detenninat pe unli cercetători să le considere. impreună, partea unui ansamblu de la care s-au păstrat fragmentele unei podoabe de cap sau porțiuni din decorul unel mantı, venitá din atelierele venețiene pentru volevodul Ștelan cel Mare"'.

Dar mormântul lui Ștefan ar fi trebuit să fie golit de podoabe. dacoă dăıı crezare lui lon Neculce care intr-"O Samă de Cuvinte" spunea că lui "Vasilie vodā i s-au întunecat mintea spre lăcomie de au stricat mănăstırea Putna. gândı́nd cã va găsi banı și n-au găsit. Șı s-au apucat să o facă din nou larăș, precum a fost și nu i-alı ajutat Dumınezeu să o facă. Că au zidit-o numai din temelie din pămānt pãnã la fereșt1..."

Deși ruinală, tot "au venit Timuș Hmielnıțkı cu sumedenie de cazacı șı alı ars mainăstirea in anul 7161. mal 18" nota cu amárăciune pan Vastlie pe un minei de aprilie ${ }^{12}$.

El se întorceau atunci din Tara Românească, înfrânți după bătălia de la Finta în timpul primel Incursiuni în ajutorul lư Vasile Lupu. și, ce-au mai aflat la mânăstire au luat cu ei netulburați, dincolo de Nistru.

În timpul celei de-a doua incursiunt, incepută în august, cazacil s-âtı indreptat direct spre Suceava, dar, spune Miron Costin "cum au sosit el singur /Timuṣ/ și au mărs la Dragomirna mănăstırea, tară alte cete pe la toate mănăstirile au purces in jacu.

Ce Timuș au apucat cu o zi inainte de au intrat în tabără, iară celelalle cete de sărgu le-au plătit Dumnezeu platã pentru jacul caselor sale, că au mărsu oastea lui Ștefan vodả de le-au ieșit inainte, de le-au ținut calea și s-au topil câteva cete cu totul"'as.

Cu sigurantā cã cel ce ne-a lāsat cele douã tezaure. a fost la Dragomirna pentru cả un fragment de potir din argint poartă inscripṭ̂a de danie a mitropolituluì Atanasie Crâmca către ctitoria sa'n'.

Dar, printre plesele tezaurului de argint sunt și trei farfurii de cositor cu inscripțil armenești, una dintre ele datatã la $1564^{\text {'r.". }}$

Acestea provin de la Zamca, mânăstirea annenilor dín Suceava, la Jefuirea cărela a asistat îngrozit Paul de Alep, atunci când cazacil "au pus mâna pe toate averile lor /armenilor'/ pe lucrurile lor de preț. pe aurul lor. pe mărgaritarele lor și pe nenumăratele lor giuvaeruri fine" ${ }^{\text {"ts. }}$ 
Ca piesele descoopente pe platoul cetății Sucevei să provină de la Putna. ar Irebui ca după jefuirea mânăstirii, din mai, cazacii să fi revenit in augusı., să

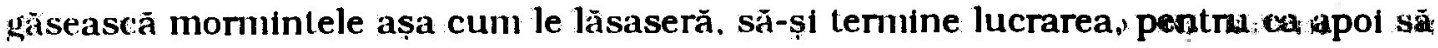
reușească să ajungă la Suceava in tảuără. netulburați.

Dar despre aceástă a doua jefuire a Putnei lipsesc documentele.

În schimb, unele mărturili arheologice. deși sărace. sustîn datarea Lezaumului de la Suceava in timpul.domniei lui Ștefan cel Mare.

Cele 12 rozete din argint aurlt descoperite la Târgșor ${ }^{17}$ \$̧i 2 fragmente de rozete din argint din tezaurul de la Păun, comuna Mihăllești, jud. Botoșaní ${ }^{\prime H}$, datate intre secolele al XV-lea și al XVl-lea, sunt unicele piese descoperite pe teritoriul rouánesc similare rozetelor dín tezaurul de la Suceava.

Însă, acestea reproduc intr-un materlal mal puțin prețios, dar cu o circulaṭie mai largă un model de lux a cărui cunoașteré nu se putea reduce numai la piesele de la Suceava.

Din punct de vedere artistic, arla de răspândire a pieselor similare aplicelor si fragmentelor de podoabă de la Suceava nu se reduce la atelierele venețlene; ea cuprinde lumea citcum-mediteraneană și pontică, cea în care s-au creat. răspândit. multiplicat și moṣtenit produsele mauro-bizantine, incepând din secolul al.ıX-lea, dar mai ales din al Xl-lea.

Toluṣi, printre produsele acestei arte nu am intîlnit nici un obiect de orfevrărie sau textil, al căruí motiv decorativ să cuprindă aplice similare in ansamblu sau parțial.

Numai cătorva dintre ele le-am găsit inrudirlle, dar și acestea cu datare problematică: :

Floarea de crin - in tezaurul de la Suceava, intr-un isingur exemplar, tipul 11. a fost un motiv decorativ de origine maură, micro-aslatică. cu care s-au impodobil miniaturi bizantine, arabe, evreiești. armene. din, secolul al XI-lea până in secolul al XIV-lea'", brocardurle Italiene, mai ales cele venețiene, din secolul al XIV-lea și o singură piesă de aur, " coroana lui Vladimir Monomahul”,"

Ea à fost atribuită pentru prima dată cneazului Kievului, Vladimir (11131125 ) in Inventarele marelui duce al Moscovei, Ivan al IV-lea ( 1547-1584 ) sub denumirea de " coroana de aur 
Tradiția croniçăreascà mal târzie afinnà cà Vladiınır ar f̂ preluat-o de la hatmanul Kaffel și ": după sine le-au lăsat creștinilor monarhi rusești pentru incununarea spre cnejje ${ }^{.23}$.

De aceea unii istorici de artă ruși, au socotit legendară atribuirea coroanei lui Vladimir Monomahul și au datat-o din punct de vedere artistic la sfárșilıul secolului al XIII-lea și inceputul secolului al XIV-lea, consideránd-o o creatie a atelierelor mauro-bizantine. poate chiar din Sicllla ${ }^{2 / 1}$.

Floarea de crin la care ne referim. așezată in mijlocul a șase din cele opt sectoare ale calotei semisferice a camilafcăl. esle redată numai in conturul petalelor, bordate cu perle de aur.

Și loo din zona Kaffei, de unde ar vení cantlafca, precum și de la Ecalerinoslav. intre mai multe fragmente de mătase bizantină. s-au găsit 6 și respectiv 34 aplice de aur decorate cu filigran vennlcular, datate in secolul al XIIlea. Ele măsoară aproximativ un centimetru și sunt foarte asemănătoare cu cele din grupia $8^{t:}$.

O sinteză Intre tipul menționat in rándul de mai sus și cele in fonnà de mànuse sau copac. tipul al 7-lea de la Suceava. sunt cele 9 plăcute de aur filigranat, cu càte o turcoazà in mijloc. deıpe bordura camilafcảı Constantẹi de Aragon. soția lui Frederic al ll-lea de Hohenstaufen, inmormantatà la Palenno un $1222^{2 *}$

Aceasta a fost atrlbuită atelierelor siciliene puternic influențate de arta maură pentru care acest sistem de plăcuṭe filigranate ar reprezenta "arborele. vieți1".27.

Ca și in cazul atribuiril coroanei kievene lui Vladimir Monomahul. unii cercetātori contestă apartenența coroaned palennitane Constantel de Aryon și 0 datează in secolul al XIV-lea ${ }^{2 \mu}$.

Pe conturul aplicelor dreptunghiulare completate de rozela lobatã, au fosit decupate și plăcuțele de aur ematlate clolssonnee, ale celor două diademe kievene. din secolul al Xll-lea ${ }^{2 \sharp}$. plăcuțele de argint stanțat, tot de la o diademā. din tezaurul de la Macoviște. jud. Caraș - Severın" și din necropola de la Pojarevac (lugoslavia)". ambele datate la sfârșitul secolului al XIII-lea și inceputul secolului al XIV-lẹa.

Dar, păstrând aria de identificare numal la piese similare din aur decorate cu filigran. tennenif de comparațe se reduc abia la patru din cele 12 tipuri pe care. 
le aveu, datate din secolul al XII-lea pạnă îțtr-al XIV-lea, și provenind din ateliere siciliene și birantine.

Dar, atelierele siciliene iși restrâng activitatea treptat, incepând de la mịlocul secolului al XIll-lea. ${ }^{x 2}$ lar după ${ }_{1}$ căderea Constantlnopolului la 1204 produsele de factură.bizantină s-au lucrat in nolle state întemeiate prin împárțirea imperiului in Pen. Balcanică. Asia mică șl in jurul Măriı Negrex".

Pentru cele patru fragmente de podoabă am găsit similitudinı intr-un tezaur expus la Wallter's Gallery - Baltimore, USA. compus din 45 de piese din aur descoperite lângăa Cordoba (număr de inventar 57595) șl datat in secolele X-XI.

Acest tezaur este alcătuit din aplice flligranate, plate, în forma stelei lui David. aplice în fonnă de peștișor, filigranate, sudate pe o bentiță îngustă pe margine, cercel semilunari și 11 aplice filigranate formate dín câte 3 elemente decorative sudate pe o foale de aur și un al 12-lea format din 4 elemente la care e atașal un cârlig.

La cele 11 aplice cele 3 elemente componente sunt dispuse liniar și sunt formate alternativ din casete pentru pietre sau perle șl semlsfere din flligran cu o granulă in vârf́ semlsfere Identice cu cele de la mărgíca de aur a cercelului descoperti la Enlşala șı din argint la cerceii din tezaurele de la Oțeleni și Volnești. judetul lași, din secolul XIII.

Cea de-a 12-a aplică sau capă de centură are cele 4 elemente dispuse rombic și constituite la fel cu cele 4 fragmente de podoabă de la Suceava, adică: peretilı cillinıdrelor alcătuite, din trese de flıre răsucite care formează zone inelare despărțite de un fir neted, ondulat vertical șl mărginite de granule.

Pànă la cunoașterea tezaurului de lāngă Cordoba, am considerat că există douā grupărı de ateliere care realizau lucrăr filigranate: unele din secolele IX-XIII. unde firul era dispus circular și cordiform și altele din secolele XIII-XIV la care filigranul are forma unor crenguțe și care realizau piese de tipul celor 4 fragmente de podoabă cu fir răsucit și fir ondulat neted. Dar la tezaurul de la Wallter's Gallery întâlnim ambele forme de dispunere a filigranului ceea ce m-a determinat să împing datarea tezaurului nostru înainte de secolul al XIV-lea.

Din secolul al Xl-lea s-au "construit" in maniera primului grup de ateliere și inele de tipul celui de la Dinogețla. cercei, ca cel de la Esztergom (Ungaria), ${ }^{\text {, }}$, fibula circulară din Muzeul metropolitan de artă din New York sau cea de la Nüremberg"s.

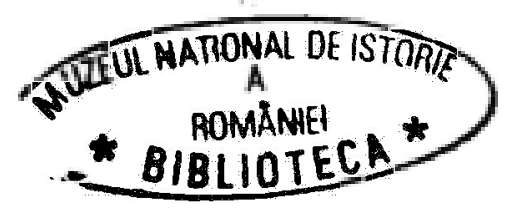


Cele patru fragumente de podoabà sunt evident elementele unei benzi decorative, a cărei Mexibilitale a fost realızatã prin sistemul de imbinare cu ajutorul inelelor perechi dintr-o singurả bentilả de metal. așezate altemativ. prin care se treceau vergele inchise la capele cu perle.

La una dintre podoabe, intre inelele de la bază. este prinsã o verịgă dublă. identică cu cele cinci descrise separal. care, fie a fosi adăugatả la descoperiłe pentru a incerca reconstituirea piesei originale. fie. provine de la o reparalie dle epoca.

Acest sisteun de imbinare ce-i làsa piesei nexibilitale. J-aun intilnit in expresia sa artisticā la o tresă de argint consideratá fragunent de brătară in lezaumul

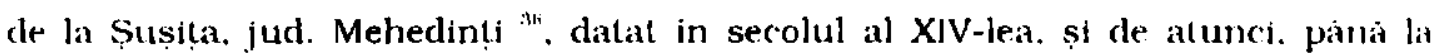
slàrṣilul secolului al XVII-lea la majoritatea coloarelor de ferecāturi de cartr.

lımpreună cu cele patru fragmente de podoabă, in compozitia benzii decoralive. au fosı prinse. probabil. și comurile - lipul 1 - ce au la bazã tubusọte canelate. la fel celor ce despart inelele perechi. de imbinare, si pe care le decortiza. de lapt.

Discul decoral cu cercur concentrice din filigran și bordură cle granule ce inchide cilindrii, la fragmentele de podoaba $A$. a lost reprodus pe unele clisitye discurile ce lonneaza centura din tezaurul de la Coveiu. jud. Mehedintl clin serolı1 it XVI-le:a".

In mod paradoxal. ('n piesele tezaurului de la Suceava oscilam conslanl intre secolul al X-lea și al XIV-lea, mál strict. intre cel de-al X-lea și al XIII-lea.

În acest interval lung aceleași motive clecorative destul de puline. au iảubràcal diversele lipuri de pocloabe din aur pentru ca după secolul al XIV-leal aceleași molive dar din arg̣inl sã clevină un adevăral manierisı.

Aceastá tehnicà a presupus o perfectà stăpannire a prelucrării melalului preṭos. mai ales la obṭmerea filtgranuluj și a granulatiej, cu ajulorul caroril Ineṣlelii au dal pieselor impresia de bogălie omamentală.

Filigranul a fost o tehnică decoralivả fără vàrstă. dàr cu două perioacle cle inflorire și ulilizare dominanta: in arta elenistică și in cea bizantina dín secolele al IX-lea pànà in al XIII-lea.

İntrucál mu se cunoṣlea trefilarea. la błjuteria elenistică. lirul se obline:ı prin ciocănirea foil de melal și läierea unor benzi foarte subtiri. 
Abia in secolul al IX-lea, călugărul Theofilius descrie pentru prima dată lletoda de obținere a firelor de metal prin tracțiune. El spunea cá "mai intài desenăm șuvițe de fire mai subțiri sau mai groase de aramă sau argint /.../ luănn o bucală de stejar subțire sau fag și facem multe găuri in ea cu fier inroșit. Prin aceste găuri tragem firele ......ı.

Metoda lut Theofilıus este greu de folosit, aproape imposibilă, pentru cà in lemmn nu se pot face gāuri netede de sub un milimetru diannetru, pe de-o parte. pe de alıā parte. la scurt timnp. chiar dupã o prînā folosire, gaura se lărgeṣte intrucuàt materialul este prea moale, iar firele se rup.

Astăzi. pentru a obține o scădere a diametrului firului de la 2 la $1 \mathrm{~mm}$ sunt necesare 16 găuri succesive, iar intre 1 și 0.1 mm., intre 22 ṣi 30 de găuri"'."

Cu ce fel de burghiu se puteau realiza aceste găuri in secolul al IX-lea (aind și astãzi el este o problemã ?

Intrucât. așa cum am observal la inicroscop. firul nostru este de lapl o bentità. s-ar pulea ca filiera sã fi fost realizatá dintr-o placã metalicã pe unuchija căreia s-a făcut o șănțuire finã. iar peste aceasla a fost fixalá o altã muclıie lireaplàn".

Firul simplu sau rāsucit, tăiat la dimensiunea dorită și modelat în virgúle êra dispus pe foaia de aur suport și fixat ca sã-ṣi păstreze pozilịa, pảnã la sudare.

Mài dificilà era fixarea și sudarea borclurii și a granulelor, in șiruri. pe marginea folj de aur.

Probabil cà sudarea a lost cea non-melalicã, cunoscutà încã din autichitatea elenistică. cea cu ajutorul sāril de cupru".

Pe suprafata acoperità cu clei amestecal cu o pudră dintr-un coimpus al cuprului. se așeayã firul dupã modelul dorit.

Se preferā malahiuul căruia grecii ii spuneau chiar "sudorul aurului". sau "liallul aurului"

Prin incālzire clejul ardea, jar malahitul reacțona violent. eliberànd cuprul (are intra in compoziția aurului, mal ales dacă acesta se prezenta in fol subṭiri.

Ín punctele de sutură. cupnul fonıła impreună cu aurul un nou aliạj cu caratạj maì scãzut. De ajci cred cá survine tillul scăzul al aurului ręultal diı́ malizele ENR. precum și ręultatele diferite de caralaj la același obiect. in func!lie de lecoll amalizat. 
Deși in perioada la care ne relerinl. secolele XI - Xlll, meșterii și piestelo rirrulau liberi. atelierele importante de bịulieri s-au inființat in intreaga Europă. in juml curtilor regale. fiecare cu specificul si secrelele ei. dintre care. cea sicilianti era cea maj cunosculă și mai creativāi dupả cea bizantină .

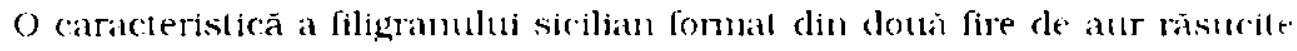

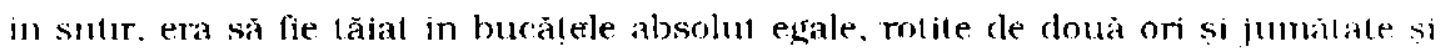
dispus in șinuri cal mai regulat posibill":

Un alt sistem. in palmete corclifome a fost clispus pe plàculele moi

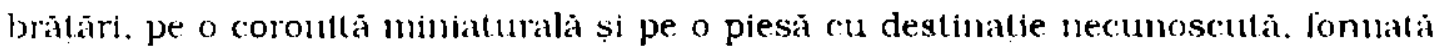
din roi cilindrii minusculi, descoperite la Szèkesfehérvatr. in 18:39. in 110muanul lui Lardislau al lll-lea. Ciul Constantei de Aragan. morl la 1205". Aceeași dispozitie are filigranul de pe plàcutele și manerul sceptrului regal maghiar. la lel ca cel de pe rncea care fommeaba arcul coroanei maghiare, a cărei clabare rămàne o problem deschisisat"

Wnii istorici de arlä mashiari sunt de părere cã acest motiv decoraliv clin filigran a fost creat chiar in atelierele de la curtea regilor appaclieni" posibil. clar de (alle bijulierii veniti din Sicilia sau din Bizant.

Firul rotll in jurul unei grianule sferice de metal sau, sub fonmă de dantelí "ll noduri in fonmá de melcișori. apare mai ales pe piesele atribuite atelierelor siciliene ${ }^{1 \overline{7}}$.

Pe coroana lui Vladimir Monomahul. ca și pe o cruce cle rugăciume de la raledralir episcopiei din Esztérgom, dalala aproximaliv in secolele XII - XIII. [irul râsucil si aplatizat fonneazá o spirala lark cleschisă. in interiorul căreia este clispus uII șir de bucle situ virgule ce dau iupresia ca se desprind din firul principal. Acest

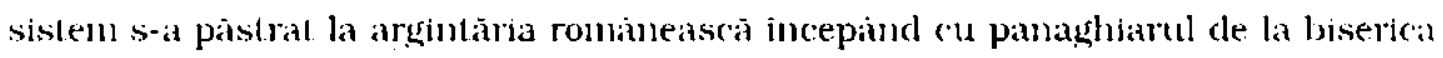

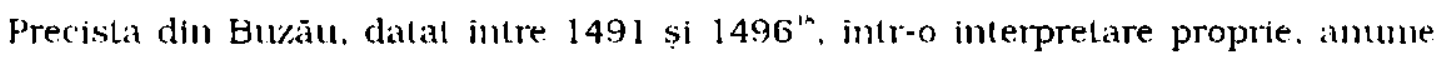
sub fommá de șiruri de vrejuri dispuse de o parle și de alta unei linii mediane

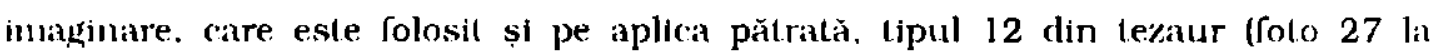
microscop).

Dar filigraumul de la aplicele de la Suceava se prełintă ca niṣte virgule. carre. pe suprafete mici e la fel cu cel de pe pandantivul in fonmã de sâmbure de mār de la cerceji descoperiți in necropola voievodală de la Pulna:'. (fijg. 29)

Se mai poate vedea și pe rama unei iconițe din secolul al XV-lea din colectiile Muzeului de Islorie din Moscova"". 
Acest sistem de filigran. in mod evident. mai ales dupà studierea lui la microscop. (fig. 31) se prezintã din punct de vedere tehnic. mult mai simplu comparativ cu cele mentionate mai sus.

In conchuzie. din puncl de vedere artistic. prin similitudinile silte și prin lispumerea liligmanului. aplicele din lezalur se dateaza din secolul al Xl-lea pana la slarșilul secolului al XIll-lea. cel tárziu. incepulul secolului al XIV-lea.

Sillarea lesaumului de la Suceava cu exactilate intr-o structurà stilisticà ar Hecesila un studiu exhaustiv al artelor circum-pontice și micro-asiatice. mai ales : crelej armene. care a fost supuse nuej dluble influente: bizantine și maurã.

Rezolvarea acestui dezideral. completal de descoperirea unor noi izome releriloare la evenimentele din 1653, ne-ar da posibililatea sá stabilim dac'a aplirelte frovu de liı o piesà de costum sau de la un object liturgic.

(:ele opt foile dreptumghiulare stantate cu molive vegelale (fig. 10) au rmusliluil. probabil cadrul tuei tcoame sau al copertij unti telraevangheliar. Dillanea lor cal si a celor cinci plic'i cu baghele. mai mult ca sigurur de aceeași limctimalitalte. este foame lambà.

Mai ușor de anializal esle motivul de volute pe fond punclat al plàcii

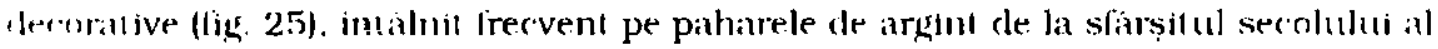

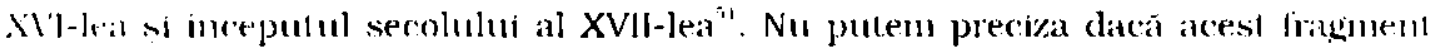

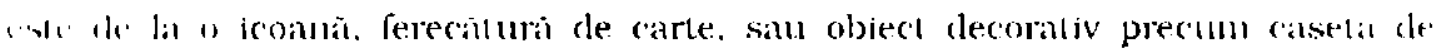

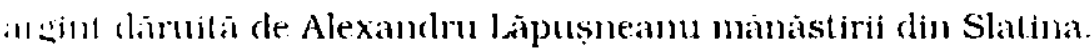

Jeci. tezaurul de lal Suceava este compus din piese care se dalleazat

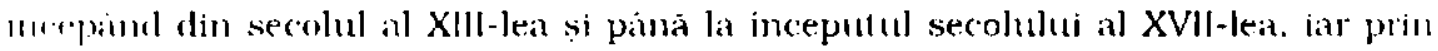
lur

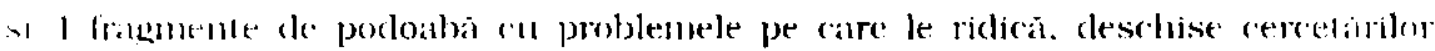
nherionate 
1. Miron Costın. Opere. București. 1958. p. 158

2. Ibiclem. p. 161

3. Ibickem. p. 164

4. Trifu Martinovici. in MCA. V. 1959, p. 598

5. Miron Costin. op. cil. p. 159

6. M. M. Popescu. Podoabe medievale in lärile românc. 1970. p. 69 - 70, cat. 151 $151 ;$

7. Dimitrte Dan. Mänástirca și comuna Pulıa. 1905. p. $46-47$

8. Ibidem

9. Ibidem. p. 47

10. Cortna Nicolescu. Istoria costumului de curte în tärile române. secolele XIV XVIII. 1970. p 171. și. Idem. Arta epocii lui Stefan cel Mare. Relatille cu lumea occiclenlalá. in SMIM. VIII. 1975. p. 89

11. Ion Neculce. Letopisetul Tärii Moldovei. 1975. p. 22. De altiel, Gheorghe Rakuc/x a desfăcul mormantul lui Sigismund de luxemburg. la 1638. din Oradea: In Vatlai Erzsebet. Margilszigeti korona. in Bp. Reg. XVIII. 1958. p. 193.

12. Ennil Turdeanu. extras din Cercẹări literare. V. 1943, p. 116

13. Miron Costin. op. cil..( nota 1 ). p. 162

14. Muzeul National de Istorie. nr. Inv. 8611

15. Infomația și descrierea pieselor din fișele lui Radu Popa.

16. Paul de Alep. Cálăloria lui .... in Călători străini despre tările rouıane. VI. 1976. p. 99

17. Sunt in expunerea Muzeului de Istorie din Ploiești.

18. Eugenia Neamțu. Gr. Foit. in Arheologia Moldovei, VII, p. 359, fig $1 / 2$

19. Jean Ebersoli, Les arts sompiuaires de Byzance. 1923. p. 89. 91: Heicle Buschhause. Die Krim als. Letzles Zemtrum der Kreuzfalirerkunst und thre... in Byzantino - bulgarica, VIII, 1986. p. 163. 168.

20. Antonio Santangelo. Tessuti Do Arte IIaliani dal XII al XVIII secolo. Electa Editrice. Milano. 1959/. Pl. 23, p. 20, 22.

21. The Ancient State Regalia. The Armoury in the Moscou Kremlin, PI. 2. lig. 1 
22. Ibidem; vezi și Andre Grabar. Une cotmone du debut du XIII siecle et les Coilfures drapparal fominines, in Ant de la fin cle L:Anliquile el du Moyen Ages. II. p. 1125

2.3. Nicolate Iorga. Operele Ini Gheorghe Brancovici. in Revisla Istorica. III. 2 - 6. $1917 \cdot$. . $68-69$.

24. Veri lrimilerea 21.

25. Anrle: Grabar, op. cil. p. 1127 . Sigs. 7.

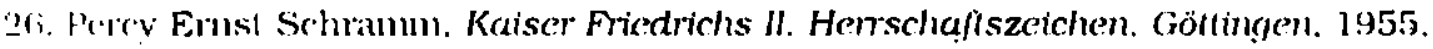
1). $11-15$.

27. Angelo lipinsky. Les arts somptuaines en Jlatie meridionale et en Sicilie (st)o l20(1) "xiras din "Cahiers de civilisation medievale". X - XII siecles. XVIII Anmer. no. $: 3$ - 4 jullel - decembre. 1975. p. 200

2R. Jügen Alseler. Kronen. Herrschaflszeichen derWell. Wien.cat. 6

29. T. O. Davidova. Kieuskii Muzei Istoriceskih Dragatenosici, Kiev, 1974. cat. 111 $11: 3$

30. Ilie laum, Tezaumul de la Maconiște. jud. Caras Severin. A.M.N.. XX. 1983. p. 515

:3 [3!jallat Radojkovici. Jeuwelry with Serbs. (XII - XVIII century). 1969. p. 234 - 2:35. 112. $122 \cdot 12: 3$

32. Angrelo l.ipinsky. op. cil..( nola 27). p. 101.

:3:1. Jean Ehersolt. op. cit., p. 109 și urnu.

34. Eva Kovates. LOrfevierie romane en Hongrie, 1974, p. 22; și Eva Kovacs. Zsuzsa l.ovąs. Dic Ingarischen Krönungsinsignien ${ }_{2}$ Korvina kiado, 1980. p. 58.

:5. M. Schulye Doutlann. Zuesi Hochmittelalterliche: Goldscheibentibeln aus Italien. in Arharologisches Kolre'spondenzhla!!. 20. 1990, p. $463-470$.

:31. I. ucian Roṣu. Tezaurul medieval de la Șușila. in "Revista muzeelor". 4. 1964. p. $2:\{7-2: 38$. fi.s. 2.

:37. M. М. Рopescu, op. cil., p. 49, cal. 42. Jik. 18.

ix. Theophilius. The Various Arts, I,ondon. p. 38

39. Ensst Folt\%, Einige Beobachtungem zu Antiken gold und Silberschmiede "whike'n in Archaeologisches KorrespondenzbalatL. 9. 1979. p. 216.

*10. Posibililatea folosirii unel astfel de filiere ne-a fost sugerată de ing. Marius Amariel, restaurator metale la laboratorul de restaurare a metalelor din M.N.I.. El a realizal și folograflerea pieselor tezaurului de la Suceava la microscop. llustratia 
lucrario o datorez lui Marius Amariei și Vlad Colị̣ă, cărora le mulțumesc și pe aceasta cale.

41. Richard Danjel De Puma. Field Museum of Natural History Bulletin. or1. 1987. p. $13-14$

42. Ibidem.

43. Angelo lipinsky. op. cil.. p. 244.

44. Eva Kovacs. Einige Probleme des Krakauter Kronenkreuzes. in Acta Hislorje Artium Humbariae, XVII, 1971, p. 260, p. 19 - 20.

15. Eva Kovac's. Zsuzsa lovag, op. cit., p. 55- 57

46. Eva Krovacs.op. cil... p. 260

47. Amgerlo lipinsky, op. cil. Ioc. cit.

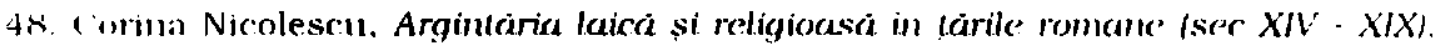
(a11. 215.

19. M. M. Popesc'u. op. cit.. cat. 17

50. Musce Historiclue, Moscou. Ieninglad. call. 16

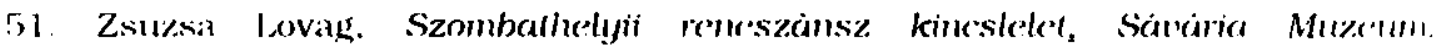
Szombahely, 1975. Pl. 4 - 6. 
"The Treasure from Suceava" was found in front of Suceava fortress during the archaelogical excavations perfonmed in 1953. It is made up of 190 gold pieces and 745 genuine pearls:

- the 17l differently shaped appliques worked in filigree are to be divided into 12 types (fig. $3-24$ and 30 )

- 4 diadem fragments (fig. 1 - 2)

-5 double links ( fig. 4)

- 8 rectangular gold sheets with vegetal motts (fig. 10)

- 6 rectangular plaques (5 with grooves. 1 with vegetal motifs 25)

The archaelogical enviromment date the buryng moment of this treasure to llie middle of the 17 th century (1653). Its pieces were robbed from the monasteries of Moldaviar.

Taking inlo account similar pleces found in Europe it was suggestert llial the applicques and diadem fragnents should be dated in the $131 \mathrm{~h}$ - 14 h centuries. These pearls and appliques embellished a hemispherical cap encled with a diadem.

The rectangular sleets and gold plaques might have been used as ornanentation elements for an icon. a book cover or a casket and they luigla be dialed in the 16 th - 17 th centuries. a more precise chating being not possible yet. 
Pl1. Fig. 1 - 2 - Fragmente de diademá:

Fig. 3 - Difertle lipuri diferile de aplice:

Pl. II. Fịs G-Aplică

Fig. 10 - Foaje reclangularà de la o icoanà sau carte

II. III - V. Fis. 11-24-Diferile lipuri die aplice

Fig. 25 - Fraganent de frecălură de la o tcoaná sau copertá de carte

Pl Vl. Fix. 27 - 28 - Imazini de aplice luate prin microscop

Figs. 29 - Capát de panclantiv descoperit la Pulna

Pll. V'll. Fí. 30 - Aplicá

Fiś. 31 - Aplicá vazulá la microscop

\section{EXPI,ICATION PIATES}

Pl. 1. Component parts of a diadein (fig. 1 - 2)

Differently shaped apliques (fig. 3 - 8 )

PI. II Apliques (fip. 9)

Rectatlgular sheel from an icon or book (fig. 10)

F'. III - V DiTterently shapes aplicues (big. 11 - 24)

Sheet from an icon or book (fig. 25)

Pl. VI lmage ol on apliques taken througlh the microscop (lig. $27-2$ )

End pandant descovered at Pulna (fig. 29)

PI. VII Aplicques (lik. 30)

Image of an apliques through the microscope (fig. 31). 


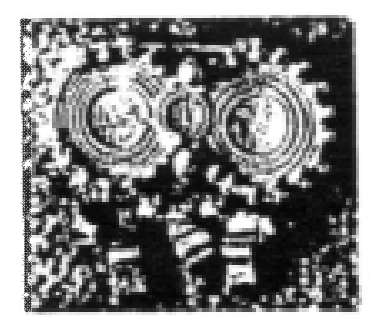

1
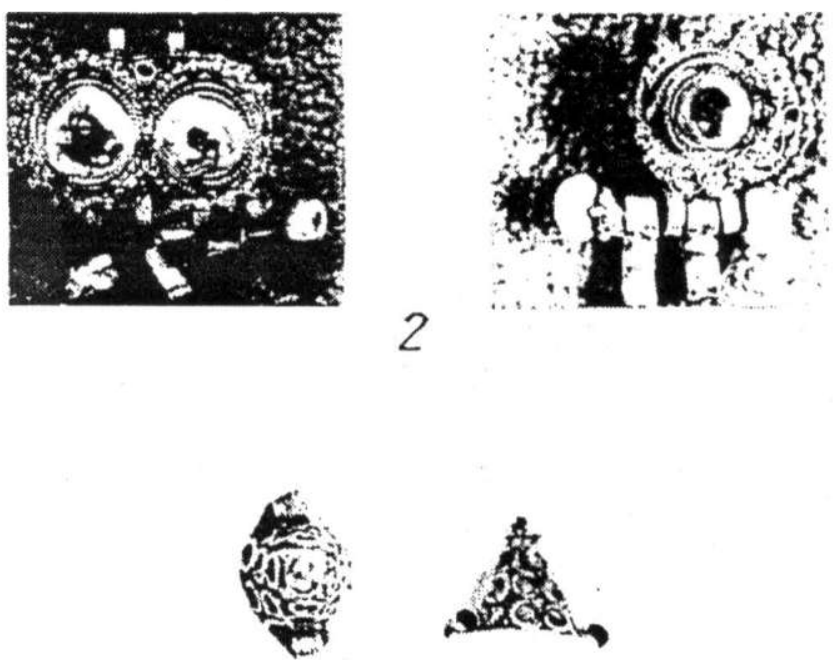

3

(2)
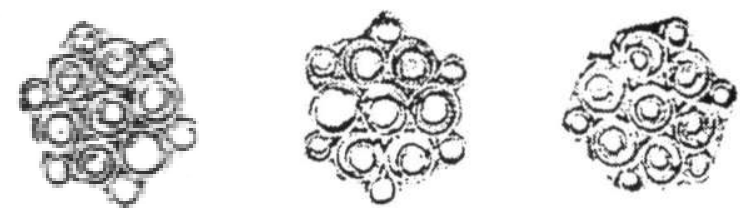

5

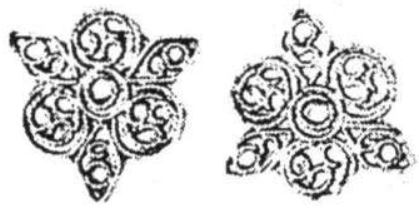

6
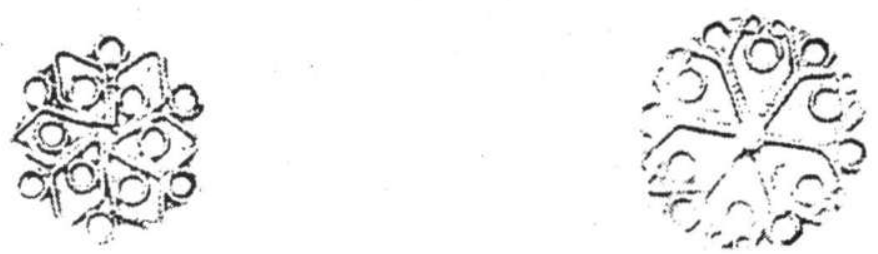

7

8 


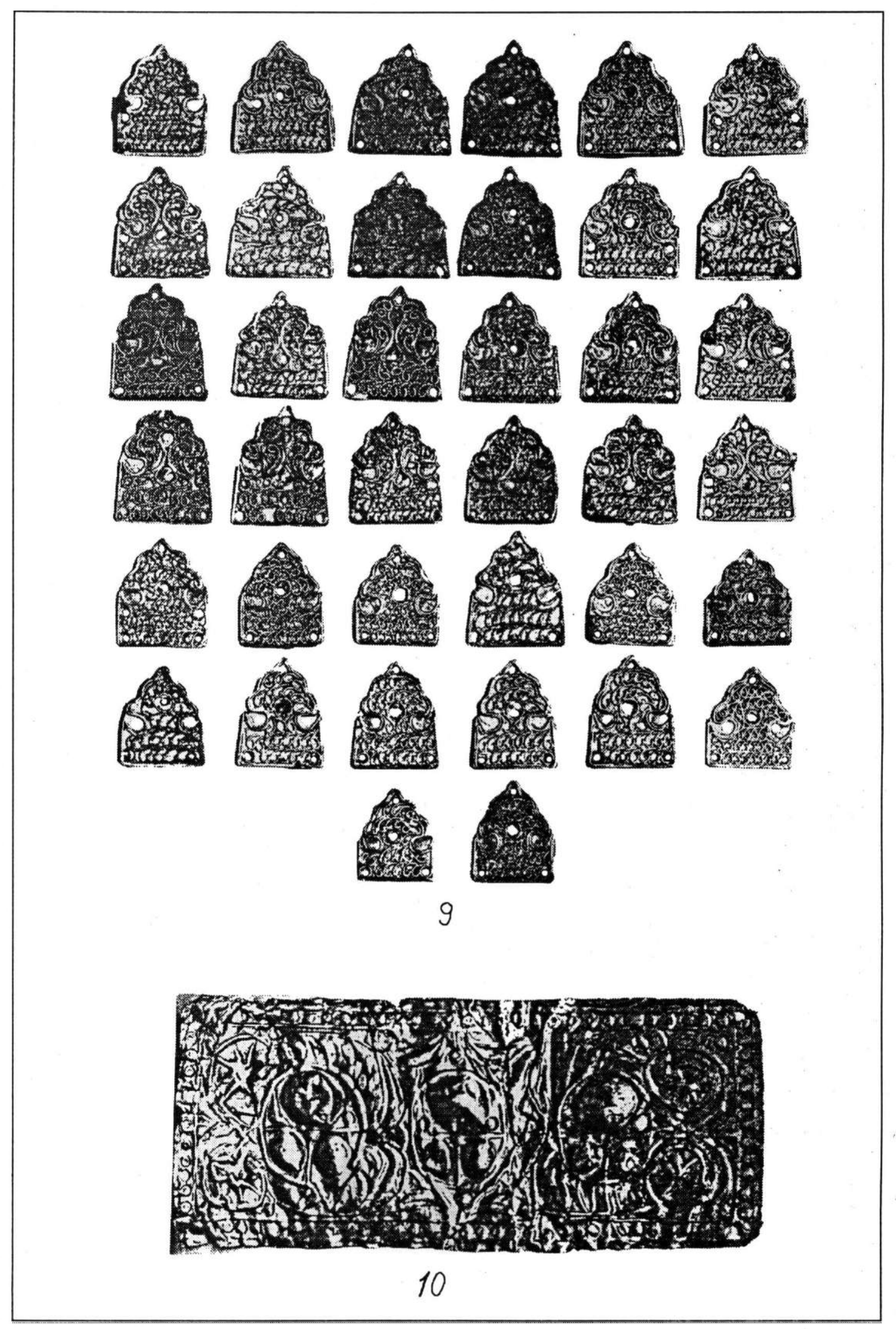

Planşa II 

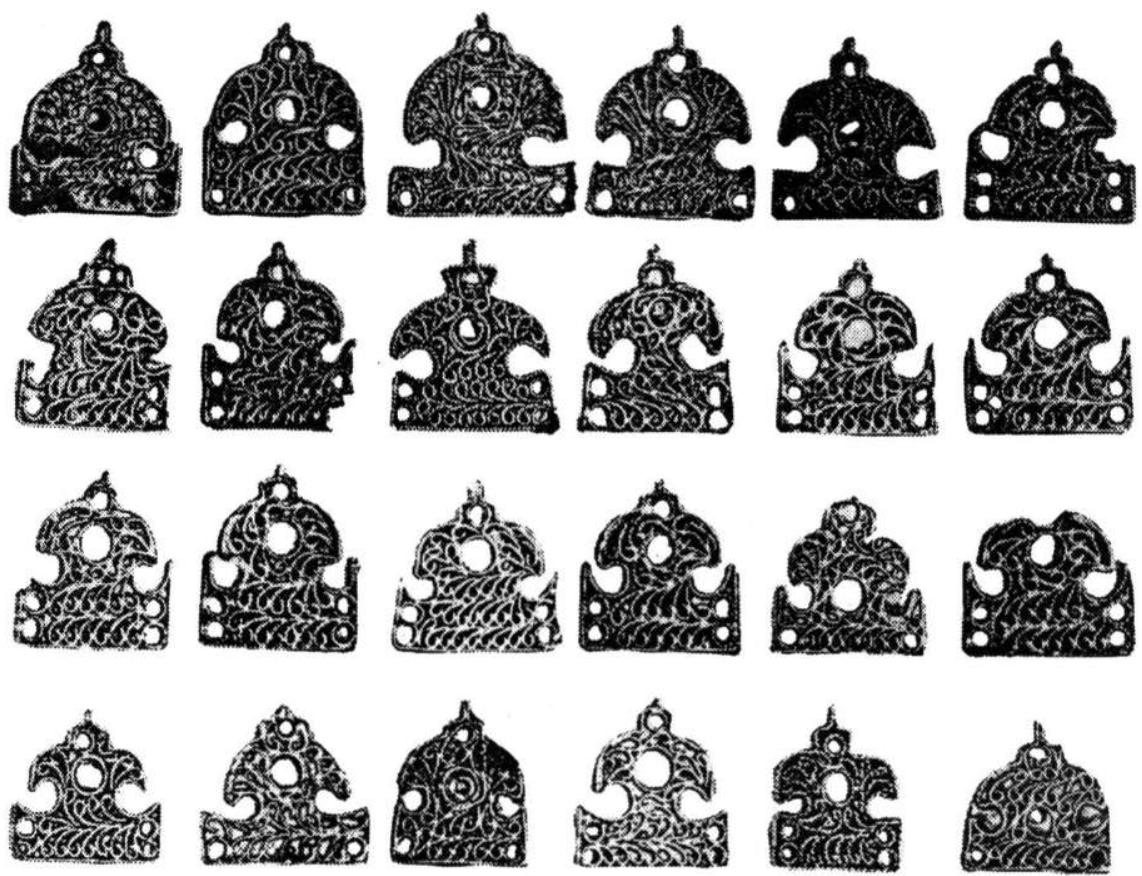

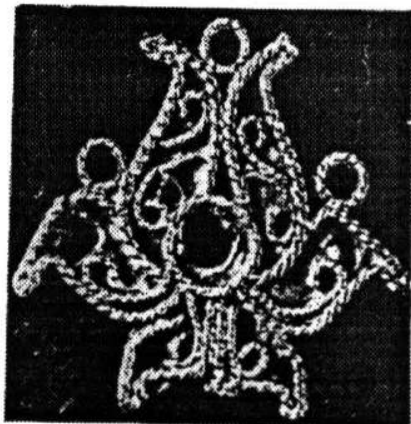

12
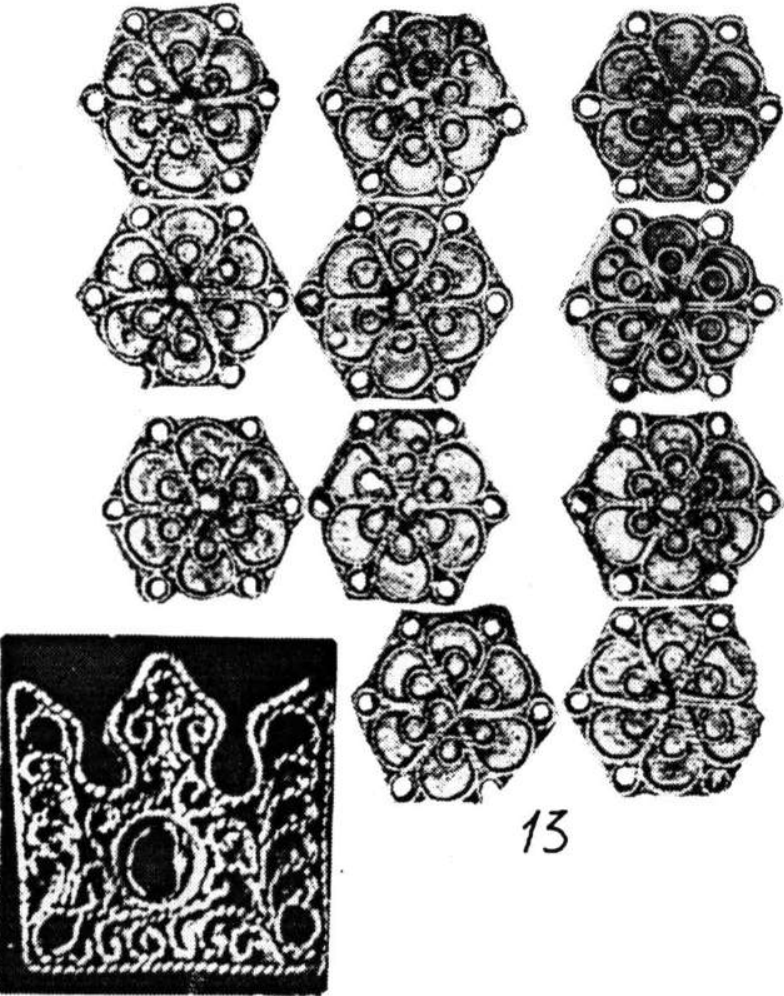

13

14

Planşa III 


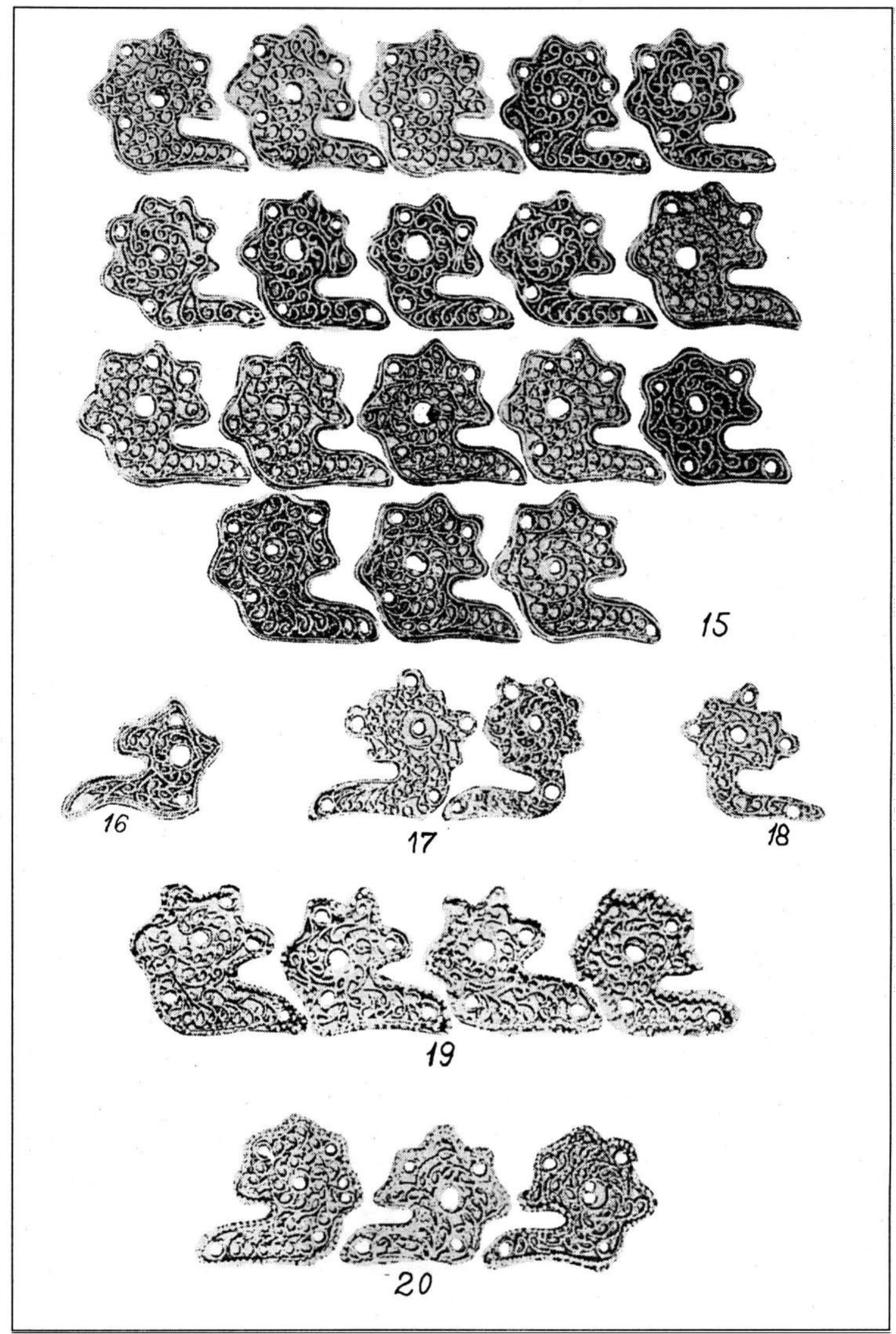

Planşa IV 

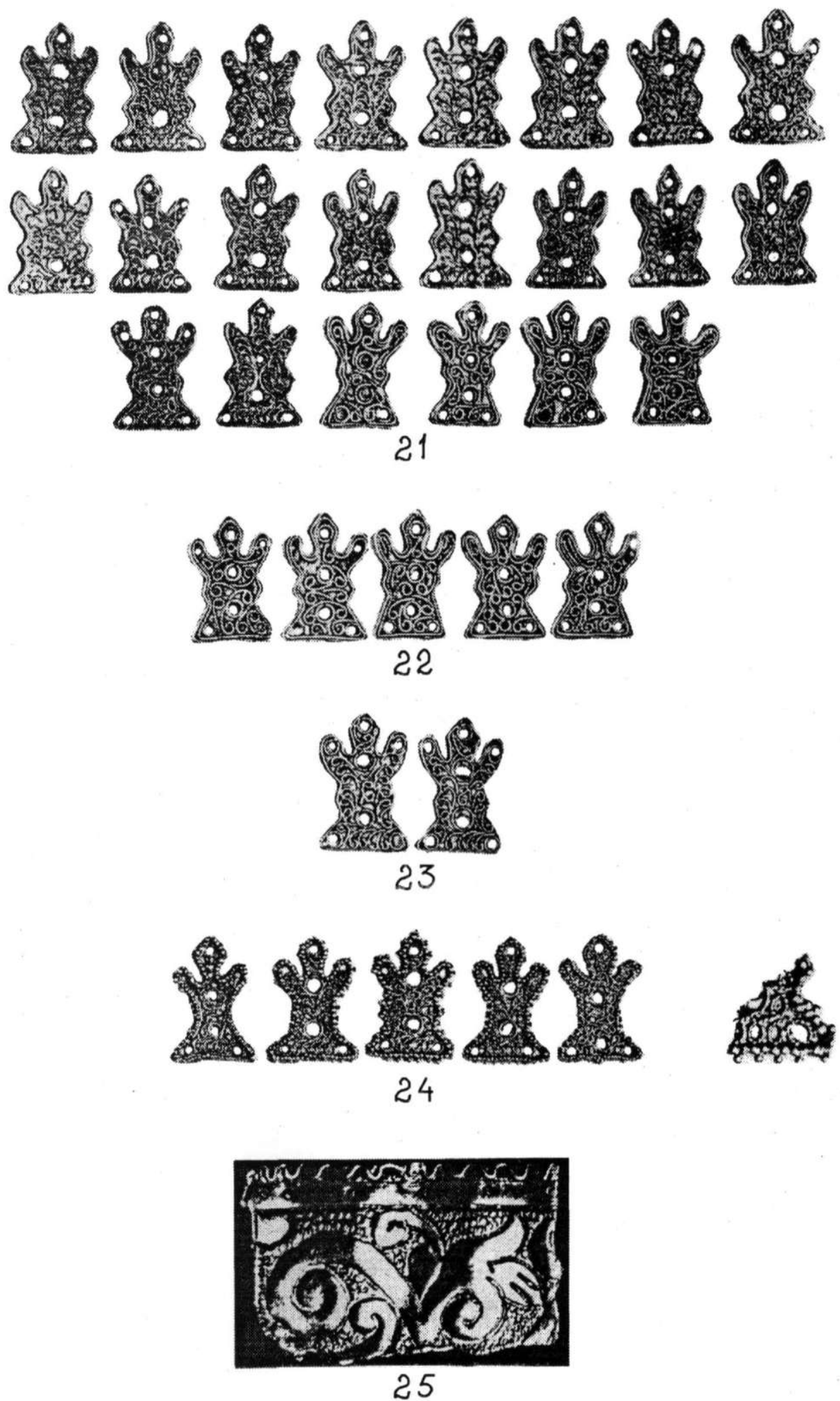

Planşa V 


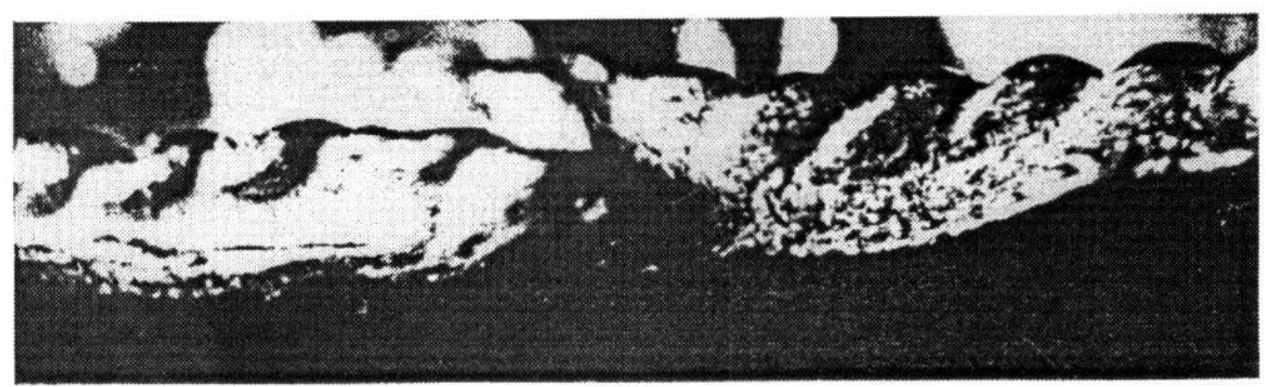

27

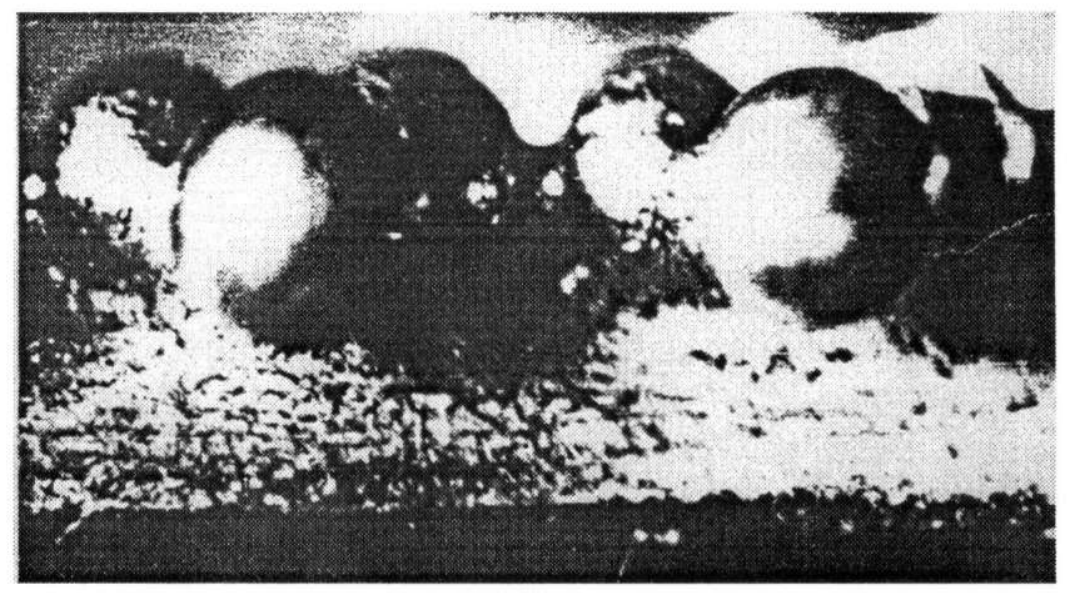

28

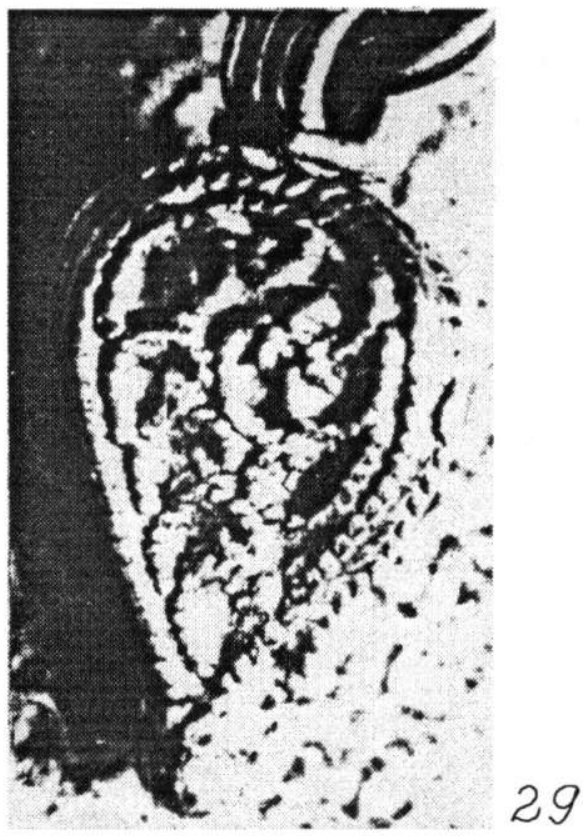

Planșa VI 


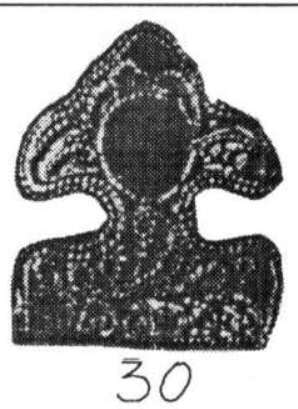

31

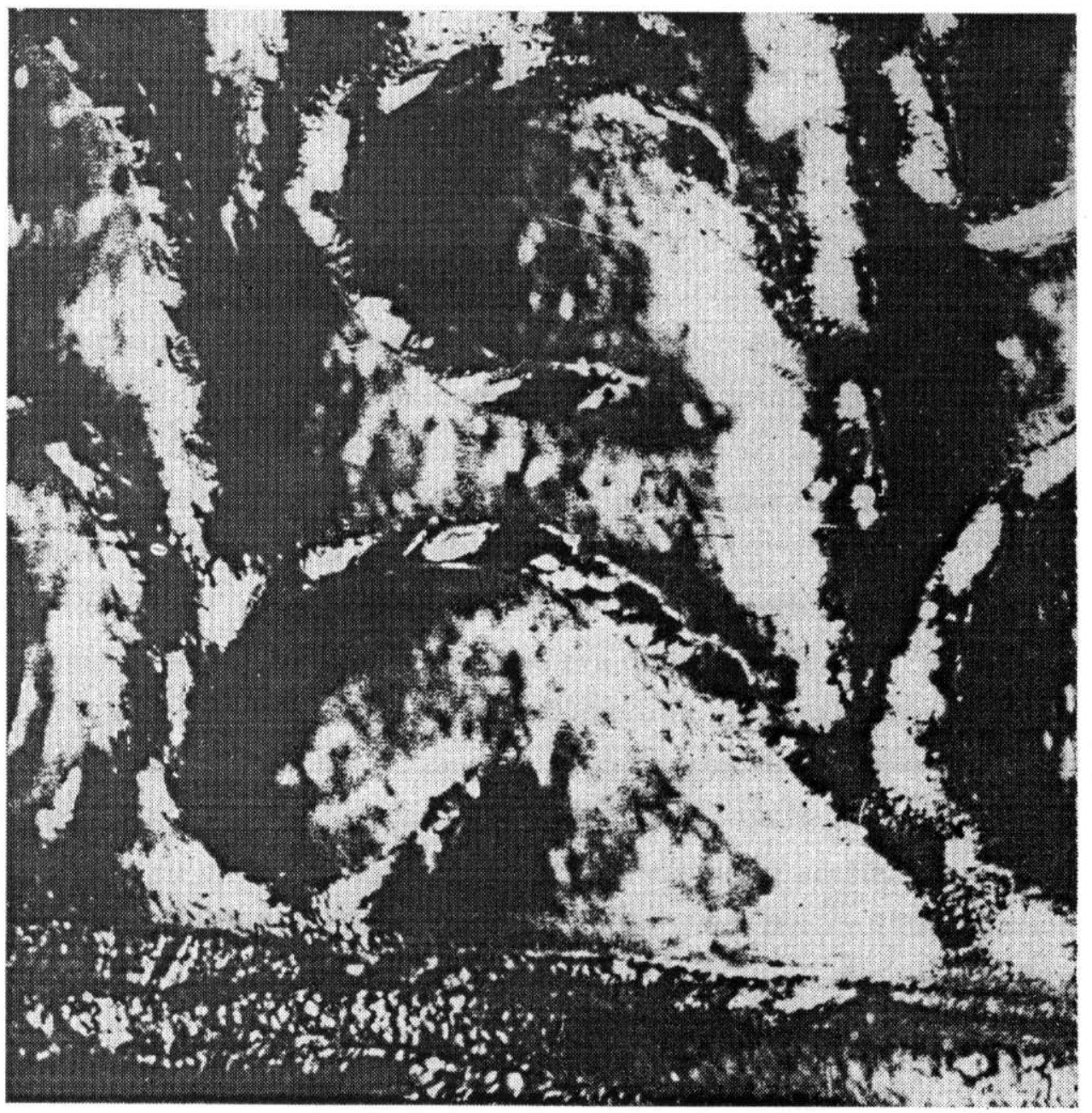

Planșa VII 